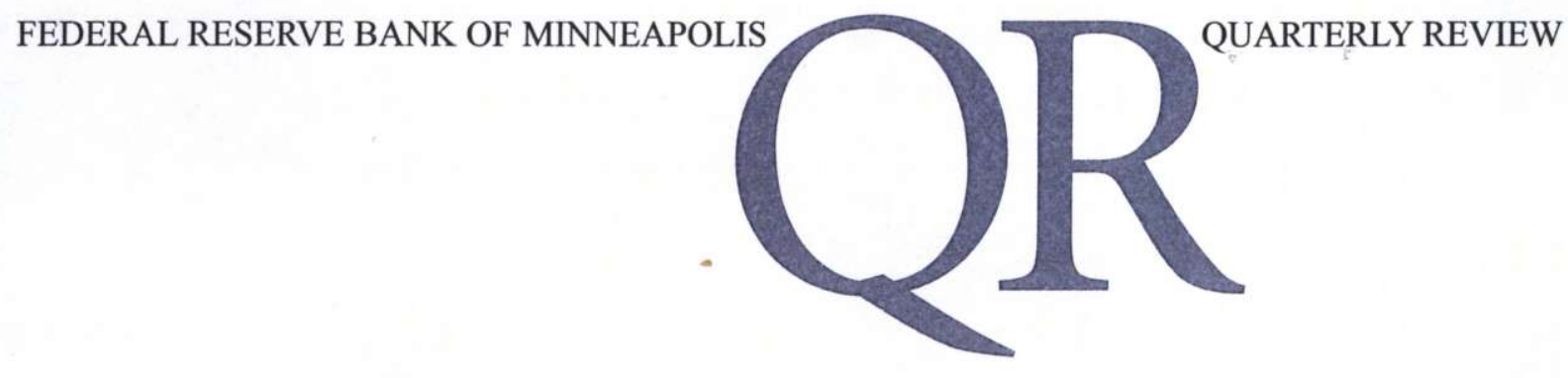

JULY 2004

Why Do Americans Work

So Much More Than Europeans?

Edward C. Prescott

Changes in Hours Worked, 19502000

Ellen R. McGrattan

Richard Rogerson 
FEDERAL RESERVE BANK OF MINNEAPOLIS

\section{Quarterly Review Vol.28, No.1}

\section{ISSN 0271-5287}

This publication primarily presents economic research aimed at improving policymaking by the Federal Reserve System and other governmental authorities.

Any views expressed herein are those of the authors and not necessarily those of the Federal Reserve Bank of Minneapolis or the Federal Reserve System.

EDITOR: Arthur J. Rolnick

ASSOCIATE EDITORS: Patrick J. Kehoe, Warren E. Weber

MANAGING EDITOR: Linda A. White

ARTICLE EDITOR: Jenni C. Schoppers

PRODUCTION EDITOR: Jenni C. Schoppers

DESIGNER: Phil Swenson

TYPESETTING: Mary E. Anomalay

CIRCULATION ASSISTANT: Rebecca Matsch
The Quarterly Review is published by the Research Department of the Federal Reserve Bank of Minneapolis. Subscriptions are available free of charge.

Quarterly Review articles that are reprints or revisions of papers published elsewhere may not be reprinted without the written permission of the original publisher. All other Quarterly Review articles may be reprinted without charge. If you reprint an article, please fully credit the source-the Minneapolis Federal Reserve Bank as well as the Quarterly Review-and include with the reprint a version of the standard Federal Reserve disclaimer (italicized left). Also, please send one copy of any publication that includes a reprint to the Minneapolis Fed Research Department.

Electronic files of Quarterly Review articles are available through the Minneapolis Fed's home page on the World Wide Web: http://www.minneapolisfed.org .

Comments and questions about the Quarterly Review may be sent to:

Quarterly Review

Research Department

Federal Reserve Bank of Minneapolis

P. O. Box 291

Minneapolis, MN 55480-0291

(Phone 612-204-6455/Fax 612-204-5515)

Subscription requests may be sent to the circulation assistant at Rebecca.matsch@mpls.frb.org; editorial comments and questions may be sent to the managing editor at Linda.white@mpls.frb.org . 


\title{
Why Do Americans Work So Much More Than Europeans?*
}

\author{
Edward C. Prescott \\ Senior Monetary Adviser \\ Research Department \\ Federal Reserve Bank of Minneapolis \\ and W.P. Carey Chair \\ Department of Economics \\ Arizona State University
}

Americans, that is, residents of the United States, work much more than do Europeans. Using labor market statistics from the Organisation for Economic Co-operation and Development (OECD), I find that Americans on a per person aged 15-64 basis work in the market sector 50 percent more than do the French. This was not always the case. In the early 1970s, Americans allocated less time to the market than did the French. The comparisons between Americans and Germans or Italians are the same. Why are there such large differences in labor supply across these countries? Why did the relative labor supplies change so much over time? In this article, I determine the importance of tax rates in accounting for these differences in labor supply for the major advanced industrial countries and find that tax rates alone account for most of them.

This finding has important implications for policy, in particular, for financing public retirement programs, such as U.S. Social Security. On the pessimistic side, one implication is that increasing tax rates will not solve the problem of these underfunded plans, because increasing tax rates will not increase revenue. On the optimistic side, the system can be reformed in a way that makes the young better off while honoring promises to the old. This can be accomplished by modifying the tax system so that when an individual works more and produces more output, the individual gets to consume a larger fraction of the increased output.

The major advanced industrial countries (the G-7 countries) are the European countries France, Germany, Italy, and the United Kingdom, plus Canada, Japan, and the United States. Comparable and sufficiently good statistics for these countries are available to carry out this investigation. The data sources are the United Nations system of national accounts (SNA) statistics and the OECD labor market statistics and purchasing power parity gross domestic product (GDP) numbers. ${ }^{1}$ The periods considered are 1970-74 and 1993-96. The later period was chosen because it is the most recent period prior to the U.S. telecommunications/dot-com boom of the late 1990 s, a period when the relative size of unmeasured

*This is the 2002 Erwin Plein Nemmers Prize in Economics lecture, presented April 21, 2003, at Northwestern University. The author thanks Sami Alpanda, Simona Cociuba, T. C. Tong, and Alexander Ueberfeldt for excellent research assistantship, as well as the participants at lectures at Berlin, the Bank of England, Industry Canada, Tokyo University, the University of Toulouse, and the University of Illinois. The financial support of the National Science Foundation under SES 9986667 is also acknowledged.

${ }^{1}$ For Italy, GDP is reduced by 20 percent because Italy's GDP statistics include estimates of the underground untaxed economy. The theory is concerned with the above-ground taxed economy, and I want GDP for this sector. This is why I do not follow Maddison (1995, pp. 241-50) and increase the OECD labor supply numbers by 16.0 percent in the $1970-74$ period and 17.6 percent in the $1993-96$ period. 
Why Americans Work So Much

Edward C. Prescott

output was probably significantly larger than normal and there may have been associated problems with the market hours statistics. The earlier period was selected because it is the earliest one for which sufficiently good data are available to carry out the analysis. The relative numbers after 2000 are pretty much the same as they were in the pretechnology boom period 1993-96.

I emphasize that my labor supply measure is hours worked per person aged 15-64 in the taxed market sector. The two principal margins of work effort are hours actually worked by employees and the fraction of the working-age population that works. Paid vacations, sick leave, and holidays are hours of nonworking time. Time spent working in the underground economy or in the home sector is not counted. Other things equal, a country with more weeks of vacation and more holidays will have a lower labor supply in the sense that I am using the term. I focus only on that part of working time for which the resulting labor income is taxed.

Table 1 reports the G-7 countries' output, labor supply, and productivity statistics relative to the United States for 1993-96 and 1970-74. The important observation for the 1993-96 period is that labor supply (hours per person) is much higher in Japan and the United States than it is in Germany, France, and Italy. Canada and the United Kingdom are in the intermediate range. Another observation is that U.S. output per person is about 40 percent higher than in the European countries, with most of the differences in output accounted for by differences in hours worked per person and not by differences in productivity, that is, in output per hour worked. Indeed, the OECD statistics indicate that French productivity is 10 percent higher than U.S. productivity. In Japan, the output per person difference is accounted for by lower productivity and not by lower labor supply.

Table 1 shows a very different picture in the 1970-74 period. The difference is not in output per person. Then, European output per person was about 70 percent of the U.S. level, as it was in 1993-96 and is today. However, the reason for the lower output in Europe is not fewer market hours worked, as is the case in the 1993-96 period, but rather lower output per hour. In 1970-74, Europeans worked more than Americans. The exception is Italy. What caused these changes in labor supply?

\section{Theory Used}

To account for differences in the labor supply, I use the standard theory used in quantitative studies of business cycles (Cooley 1995), of depressions (Cole and Ohanian
Table 1

Output, Labor Supply, and Productivity

In Selected Countries in 1993-96 and 1970-74

\begin{tabular}{|c|c|c|c|c|}
\hline \multirow[b]{2}{*}{ Period } & \multirow[b]{2}{*}{ Country } & \multicolumn{3}{|c|}{ Relative to United States (U.S. = 100) } \\
\hline & & $\begin{array}{l}\text { Output } \\
\text { per Person* }\end{array}$ & $\begin{array}{l}\text { Hours Worked } \\
\text { per Person* }\end{array}$ & $\begin{array}{l}\text { Output per } \\
\text { Hour Worked }\end{array}$ \\
\hline \multirow[t]{7}{*}{ 1993-96 } & Germany & 74 & 75 & 99 \\
\hline & France & 74 & 68 & 110 \\
\hline & Italy & 57 & 64 & 90 \\
\hline & Canada & 79 & 88 & 89 \\
\hline & United Kingdom & 67 & 88 & 76 \\
\hline & Japan & 78 & 104 & 74 \\
\hline & United States & 100 & 100 & 100 \\
\hline \multirow[t]{7}{*}{ 1970-74 } & Germany & 75 & 105 & 72 \\
\hline & France & 77 & 105 & 74 \\
\hline & Italy & 53 & 82 & 65 \\
\hline & Canada & 86 & 94 & 91 \\
\hline & United Kingdom & 68 & 110 & 62 \\
\hline & Japan & 62 & 127 & 49 \\
\hline & United States & 100 & 100 & 100 \\
\hline
\end{tabular}

1999 and Kehoe and Prescott 2002), of public finance issues (Christiano and Eichenbaum 1992 and Baxter and King 1993), and of the stock market (McGrattan and Prescott 2000, 2003 and Boldrin, Christiano, and Fisher 2001). In focusing on labor supply, I am following Lucas and Rapping (1969), Lucas (1972), Kydland and Prescott (1982), Hansen (1985), and Auerbach and Kotlikoff (1987).

This theory has a stand-in household that faces a labor-leisure decision and a consumption-savings decision. The preferences of this stand-in household are ordered by

$$
E\left\{\sum_{t=0}^{\infty} \beta^{t}\left(\log c_{t}+\alpha \log \left(100-h_{t}\right)\right)\right\} .
$$

Variable $c$ denotes consumption, and $h$ denotes hours of labor supplied to the market sector per person per week. Time is indexed by $t$. The discount factor $0<\beta<1$ 
specifies the degree of patience, with a higher value indicating more patience for consumption and leisure. The parameter $\alpha>0$ specifies the value of nonmarket productive time for the household. Given that on a per person basis a household has about 100 hours of productive time per week, nonmarket productive time is $100-h$ hours per week per working-age person in the household. Following the tradition in macroeconomics, this nonmarket productive time will be referred to as leisure even though much of it is time allocated to working in the nonmarket sector and in the underground market sector. The important thing for the analysis is that any production using this time is not taxed.

In the model economy, the household owns the capital and rents it to the firm. This is an assumption of convenience because the findings are identical if the firm owns the capital and the household owns the firm, or if the firm is partially debt financed. The law of motion governing the capital stock is

$$
k_{t+1}=(1-\delta) k_{t}+x_{t}
$$

where $k$ is the capital stock, $x$ is investment, and $\delta$ is the depreciation rate.

The theory also has a stand-in firm with a CobbDouglas production function,

$$
y_{t}=c_{t}+x_{t}+g_{t} \leq A_{i t} k_{t}^{\theta} h_{t}^{1-\theta} .
$$

Here $y$ denotes output, $c$ consumption, and $g$ pure public consumption. The capital share parameter is $0<\theta<1$, and the total factor productivity parameter of country $i$ at date $t$ is $A_{i t}$. I will not specify the process on $\left\{A_{i t}\right\}$ because it plays no role in the inference being drawn, except to implicitly restrict the process governing its evolution in a way that results in the existence of a competitive equilibrium.

The household's date $t$ budget constraint is

$$
\begin{aligned}
& \left(1+\tau_{c}\right) c_{t}+\left(1+\tau_{x}\right) x_{t} \\
& \quad=\left(1-\tau_{h}\right) w_{t} h_{t}+\left(1-\tau_{k}\right)\left(r_{t}-\delta\right) k_{t}+\delta k_{t}+T_{t}
\end{aligned}
$$

where $w_{t}$ is the real wage rate, $r_{t}$ the rental price of capital, $\tau_{c}$ the consumption tax rate, $\tau_{x}$ the investment tax rate, $\tau_{h}$ the marginal labor tax rate, $\tau_{k}$ the capital income tax rate, and $T_{t}$ transfers. I emphasize that the marginal and average labor income taxes will be very different.

All tax revenue except for that used to finance the pure public consumption is given back to the households either as transfer payments or in-kind. These transfers are lump sum, being independent of a household's income. Most public expenditures are substitutes for private consumption in the G-7 countries. Here I will assume that they substitute on a one-to-one basis for private consumption with the exception of military expenditures. The goods and services in question consist mostly of publicly provided education, health care, protection services, and even judiciary services. My estimate of pure public consumption $g$ is two times military's share of employment times GDP.

In having only one consumption good, I am following Christiano and Eichenbaum (1992). Rogerson (2003) finds that this one-consumption-good abstraction is not a good one for studying aggregate labor supply in the Scandinavian countries. One possible reason is that some publicly provided goods, such as child care for working parents, must be treated as a separate good. Often the receipt of this good is contingent on working, and this must be taken into account in the household's constraint set. However, the one-consumption-good abstraction used in this study is a reasonable one for the set of countries considered.

This is a far simpler tax system than the one employed in any of the G-7 countries. Introducing accelerated depreciation and investment tax credits would affect the price of the investment good relative to the consumption good, but would not alter the inference drawn in this article. Similarly, introducing a corporate sector, with dividends not taxed, as is generally the case in Europe, or taxed as ordinary income, as they are in the United States, would not alter any conclusion significantly. For further details on these issues, see McGrattan and Prescott 2002. What is important here is the price of consumption relative to leisure, and it is determined by the consumption tax rate $\tau_{c}$ and the marginal labor income tax rate $\tau_{h}$.

The most important parameter that will enter the equilibrium relation that I use to predict the consequences of the tax system is the utility of leisure preference parameter $\alpha$, which measures the value of leisure relative to consumption. The capital cost share parameter $\theta$ also enters the relation, but is of less importance.

\section{Key Equilibrium Relation}

The labor and consumption tax rates can be combined into a single tax rate $\tau$, which I call the effective marginal tax rate on labor income. It is the fraction of additional 
labor income that is taken in the form of taxes, holding investment, or equivalently savings, fixed. From the household's budget constraint,

$$
\tau=\frac{\tau_{h}+\tau_{c}}{1+\tau_{c}}
$$

Two first-order conditions are used to construct the key equilibrium relation that is used to predict labor supply. One is that the marginal rate of substitution between leisure and consumption is equal to their price ratio; that is,

$$
\frac{\alpha /(1-h)}{1 / c}=(1-\tau) w
$$

The other is the profit-maximizing condition that the wage equals the marginal product of labor; that is,

$$
w=(1-\theta) k^{\theta} h^{-\theta}=(1-\theta) y / h .
$$

From equations (6) and (7), the key relation is obtained, namely,

$$
h_{i t}=\frac{1-\theta}{1-\theta+\frac{c_{i t}}{y_{i t}} \frac{\alpha}{1-\tau_{i t}}} .
$$

This equilibrium relation clearly separates the intertemporal and intratemporal factors affecting labor supply. The intratemporal factor is captured by $1-\tau$, which distorts the relative prices of consumption and leisure at a point in time. The $c / y$ term captures intertemporal factors. If, for example, the effective tax rate on labor income is expected to be higher in the future, people will choose a lower current value for $c / y$, and current labor supply will be higher. The same is true if the current capital stock is low relative to its balanced growth path level. More formally, equilibrium $c / y$ is a function of the predictive probability distribution of future tax rates and productivities and the current capital stock. Knowing the value of this function and the current effective tax rate on labor income suffices for predicting current labor income.

In focusing on the role of taxes in determining aggregate labor supply, I am not implying that other factors are unimportant. Cole and Ohanian (1999) and Chari,
Kehoe, and McGrattan (2003), using the discipline employed here, present strong evidence that other factors were important in accounting for the low labor supply in the United States in the 1930s. Similarly, Cole and Ohanian (2002) present evidence that the low labor supply in the United Kingdom in the 1920s was due to other factors, and Fisher and Hornstein (2002) find that labor market distortions that increased the real wage significantly above the competitive level were the major factor in accounting for the huge decline in German output in the 1928-32 period. In focusing on the role of marginal tax rates on labor income, I want to determine what role, if any, they play in accounting for the huge differences in labor supplies across this relatively homogeneous set of market economies at a point in time and in accounting for large changes in labor supplies over time across these countries. ${ }^{2}$

The theory abstracts from many features of reality that affect labor supply, in particular, whether a married household has one or two wage earners. This issue is discussed briefly in the context of the change in the U.S. labor supply in conjunction with the change in the nature of the income tax schedule that occurred as a result of the 1986 U.S. Tax Reform Act.

\section{Estimating Tax Rates}

The theory has the household paying the taxes. Consequently, it is necessary to adjust the national income accounts to be consistent with this theoretical framework. The adjustment, which is a major one, is to treat indirect taxes less subsidies as net taxes on final product. This means removing net indirect taxes as a cost component of GDP and reducing final product components.

In using SNA data to estimate tax rates and making the distinction between prices facing producers and consumers, I am following Mendoza, Razin, and Tesar (1994). There are some important differences in the approach with my estimated tax rates being in greater part model-economy dependent. In what follows, the capital letters are SNA statistics. I assume that two-thirds of these indirect taxes net of subsidies fall directly on private consumption expenditures and that the remaining one-third is distributed evenly over private consumption and private investment. Thus, net indirect taxes on consumption, $I T_{c}$, are

\footnotetext{
${ }^{2}$ Three recent studies that address issues related to the ones considered in this article are Davis and Henrekson 2003, Nickell 2003, and Olovsson 2003.
} 


$$
I T_{c}=\left[2 / 3+1 / 3 \frac{C}{C+I}\right] I T
$$

where $C$ is SNA private consumption expenditures, $I$ is SNA private investment, and $I T$ is net indirect taxes. The motivation for this assignment of indirect taxes is that most indirect taxes fall on consumption whether these taxes are value-added taxes, sales taxes, excise taxes, or property taxes. Some taxes, such as fuel taxes on diesel fuel used by trucks that transport goods, property taxes on office buildings, and sales taxes on equipment purchases by businesses, fall on all forms of product.

The model economy's consumption $c$ and output $y$ are

$$
c=C+G-G_{m i l}-I T_{c} \text { and } y=G D P-I T
$$

where $G$ is public consumption, $G_{m i l}$ is military expenditures, and GDP is gross domestic product.

My estimate of the consumption tax rate is

$$
\tau_{c}=\frac{I T_{c}}{C-I T_{c}} .
$$

There are two taxes on labor income, the income tax with marginal rate $\tau_{\text {inc }}$ and the social security tax with marginal rate $\tau_{s s}$. My estimate of the social security tax rate is simply

$$
\tau_{s s}=\frac{\text { Social Security Taxes }}{(1-\theta)(G D P-I T)} .
$$

The denominator is labor income if labor is paid its marginal product.

In some countries, some social security taxes are savings because benefits increase with income. But this is a marginal tax rate. Often there are no additional benefits to working an additional year. In the United States, the marginal savings factor is tiny. First, when I use a 4 percent discount rate and a 2 percent growth rate in the real wage, which are numbers for the U.S. economy in the twentieth century (McGrattan and Prescott 2003), the present value of benefits is only one-quarter of the present value of contributions. Second, the social security benefit scheme is highly progressive. Third, benefits to married couples typically go up little if both people work rather than if only one works. Fourth, beginning in the early 1990s, a significant part of social security benefits is subject to income taxes for many people. Fifth, for many older workers, their current-year taxable labor income has little or no consequences for the retirement benefits they receive.

Social security taxes are listed as an expenditure of the household sector in the SNA. They include taxes used to finance health care and unemployment payments, and not just taxes used to finance retirement programs. These taxes are typically proportional taxes on labor income, and they are treated as such in this analysis. In the SNA, these taxes are treated as part of compensation when they are paid by the employer, which is typically the case.

The average, not marginal, income tax rate is

$$
\bar{\tau}_{i n c}=\frac{\text { Direct Taxes }}{G D P-I T-\text { Depreciation }} .
$$

Direct taxes are those paid by households and do not include corporate income taxes. Like social security taxes, they are listed as an expenditure of the household sector in the SNA.

My estimate of the marginal labor income tax rate is

$$
\tau_{h}=\tau_{s s}+1.6 \bar{\tau}_{i n c} .
$$

The most problematic number in my analysis is the 1.6 factor that reflects the fact that the marginal income tax rates are higher than the average tax rates. I use 1.6 because it results in the marginal income tax rate obtained using the Feenberg and Coutts (1993) methodology for the United States in both the 1970-74 and 1993-96 periods. Feenberg and Coutts' methodology uses a representative sample of tax records to compute the marginal tax rate on labor income by determining how much tax revenue increases if every household's labor income is changed by 1 percent. The total change in tax receipts divided by the total change in labor income is the Feenberg-Coutts estimate of the marginal income tax rate on labor income. I will return to this point later.

Two parameters must be specified before formula (8) can be used to predict labor supply. One is the capital cost share parameter $\theta$ in the production function. For all the countries, in both periods this number is close to the average of 0.3224 , so $\theta$ is set equal to this value. The other parameter is the utility of leisure parameter $\alpha$. The value 1.54 for this parameter is chosen so 
that the average labor supply (excluding the two outlier observations) is close to the actual value for the other 12 observations.

\section{Actual and Predicted Labor Supplies}

Table 2 reports the actual and predicted labor supplies for the G-7 countries in 1993-96 and 1970-74. For the 1993-96 period, the predicted values are surprisingly close to the actual values with the average difference being only 1.14 hours per week. I say that this number is surprisingly small because this analysis abstracts from labor market policies and demographics which have consequences for aggregate labor supply and because there are significant errors in measuring the labor input.

The important observation is that the low labor supplies in Germany, France, and Italy are due to high tax rates. If someone in these countries works more and produces 100 additional euros of output, that individual gets to consume only 40 euros of additional consumption and pays directly or indirectly 60 euros in taxes.

In the 1970-74 period, it is clear for Italy that some factor other than taxes depressed labor supply. This period was one of political instability in Italy, and quite possibly cartelization policies reduced equilibrium labor supply as in the Cole and Ohanian (2002) model of the U.S. economy in the 1935-39 period. The overly high prediction for labor supply for Japan in the 1970-74 period may in significant part be the result of my utility function having too little curvature with respect to leisure, and as a result, the theory overpredicts when the effective tax rate on labor income is low. Another possible reason for the overprediction may be a measurement error. The 1970-74 Japanese labor supply statistics are based on establishment surveys only because at that time household surveys were not conducted. In Japan the household survey gives a much higher estimate of hours worked in the period when both household- and establishment-based estimates are available. In the other

\section{Table 2}

Actual and Predicted Labor Supply

In Selected Countries in 1993-96 and 1970-74

\begin{tabular}{|c|c|c|c|c|c|c|}
\hline \multirow[b]{3}{*}{ Period } & \multirow[b]{3}{*}{ Country } & \multirow{2}{*}{\multicolumn{2}{|c|}{ Labor Supply* }} & \multirow{3}{*}{$\begin{array}{l}\text { Differences } \\
\text { (Predicted } \\
\text { Less Actual) }\end{array}$} & \multicolumn{2}{|c|}{ Prediction Factors } \\
\hline & & & & & & Consumption/ \\
\hline & & Actual & Predicted & & Tax Rate $\tau$ & Output $(c / y)$ \\
\hline \multirow[t]{7}{*}{ 1993-96 } & Germany & 19.3 & 19.5 & .2 & .59 & .74 \\
\hline & France & 17.5 & 19.5 & 2.0 & .59 & .74 \\
\hline & Italy & 16.5 & 18.8 & 2.3 & .64 & .69 \\
\hline & Canada & 22.9 & 21.3 & -1.6 & .52 & .77 \\
\hline & United Kingdom & 22.8 & 22.8 & 0 & .44 & .83 \\
\hline & Japan & 27.0 & 29.0 & 2.0 & .37 & .68 \\
\hline & United States & 25.9 & 24.6 & -1.3 & .40 & .81 \\
\hline \multirow[t]{7}{*}{ 1970-74 } & Germany & 24.6 & 24.6 & 0 & .52 & .66 \\
\hline & France & 24.4 & 25.4 & 1.0 & .49 & .66 \\
\hline & Italy & 19.2 & 28.3 & 9.1 & .41 & .66 \\
\hline & Canada & 22.2 & 25.6 & 3.4 & .44 & .72 \\
\hline & United Kingdom & 25.9 & 24.0 & -1.9 & .45 & .77 \\
\hline & Japan & 29.8 & 35.8 & 6.0 & .25 & .60 \\
\hline & United States & 23.5 & 26.4 & 2.9 & .40 & .74 \\
\hline
\end{tabular}


countries household surveys are used to estimate labor supply.

An important observation is that when European and U.S. tax rates were comparable, European and U.S. labor supplies were comparable. At the aggregate level, where idiosyncratic factors are averaged out, people are remarkably similar across countries. This is true not only for the G-7 countries, but for Chile and Mexico as shown by Bergoeing et al. (2002) and for Argentina as shown by Kydland and Zarazaga (2002). Apparently, idiosyncratic preference differences average out and result in the stand-in household having almost identical preferences across countries.

I am surprised that virtually all the large differences between the U.S. labor supply and those of Germany and France are due to differences in tax systems. I expected institutional constraints on the operation of labor markets and the nature of the unemployment benefit system to be of major importance. They do appear to be important in Italy in the 1970-74 period.

\section{Changes in U.S. Labor Supply}

An interesting feature of the data is that U.S. labor increased by 10 percent between 1970-74 and 1993-96, yet the marginal tax rate on labor remained at 0.40 . The fact that all the increase in labor supply was by married women and not by males or by single females suggests that the appropriate marginal tax rate may have fallen with the flattening of the income tax rate schedule associated with the tax reforms of the 1980s, in particular, the 1986 tax reform (McGrattan and Rogerson 1998). The U.S. Department of the Treasury $(1974,1996)$ lists the number of married households' tax returns by adjusted gross income categories as well as reports the income tax schedule. These data show that the marginal tax rate for large changes in income such as those that would occur from moving from a one-earner household to a two-earner household was significantly higher in 1972 than it was in 1994.

Households switching from having one wage earner to having two probably faced lower marginal tax rates in the 1993-96 period than in the 1970-74 period, even though the Feenberg-Coutts marginal income tax rates are the same. This possibility is illustrated in Table 3 in the example of a two-person household. In the early period, if the working individual in the household increases hours worked by a small amount, the marginal income tax on the additional labor income is 20 percent, which is the Feenberg-Coutts estimate for that period. However, if the household doubles its labor supply by switching from a one-earner to a two-earner household, the marginal income tax rate on the additional labor income is 40 percent for the numerical example in Table 3.

The situation is very different in 1993-96 when the household has two earners. Small changes in labor supply in this case are still subject to a 20 percent tax rate as in the 1970-74 period, which is what the Feenberg-Coutts method finds for that period. However, the marginal income tax on the labor income associated with switching from a one-earner to a two-earner household is only 20 percent, not 40 percent as it was in the 1970-74 period.

This issue of the effect of the nature of the income tax schedule on labor supply for households with two potential wage earners warrants more attention. Feldstein (1995) examines the consequences of the 1986 Tax Reform Act using a U.S. Treasury Department panel of more than 4,000 tax forms and finds micro evidence consistent with this hypothesis. It is further supported in the Feldstein and Feenberg (1993) analysis of the Clinton Tax Plan.

Some macro evidence is provided by what happened after the 1998 Spanish tax reform that flattened the Spanish income tax schedule in much the same way that the 1986 U.S. tax reform flattened the U.S. tax schedule. Subsequently, Spanish labor supply increased by 12 percent and tax revenue by a few percent. If the change in the factor that converts the average income tax rate to a marginal tax rate were the same in the United States and

\section{Table 3}

How a Flatter Income Tax Schedule

Affected U.S. Households With

Two Potential Wage Earners: An Example

\begin{tabular}{|c|c|c|c|c|c|}
\hline \multirow[b]{2}{*}{ Period } & \multirow{2}{*}{$\begin{array}{l}\text { Number of } \\
\text { Earners in } \\
\text { Household }\end{array}$} & \multicolumn{2}{|c|}{ Hypothetical Amounts } & \multicolumn{2}{|c|}{$\begin{array}{l}\text { Assumed Rate } \\
\text { of Income Tax }\end{array}$} \\
\hline & & $\begin{array}{l}\text { Labor } \\
\text { Income }\end{array}$ & Taxes & Average & Marginal \\
\hline \multicolumn{6}{|l|}{ Before } \\
\hline Tax Reform & 1 & 10 & 1.3 & $13.0 \%$ & $20.0 \%$ \\
\hline (1970-74) & 2 & 20 & 5.3 & 26.5 & 40.0 \\
\hline \multicolumn{6}{|l|}{ After } \\
\hline Tax Reform & 1 & 10 & 1.5 & 10.0 & 20.0 \\
\hline (1993-96) & 2 & 20 & 2.6 & 13.0 & 20.0 \\
\hline
\end{tabular}


Spain and sufficiently large to increase U.S. labor supply by 10 percent, then the predicted increase in Spanish labor supply would be the observed 12 percent. More research is needed to determine whether the hypothesis that the flattening of the tax schedule is the principal reason for the large increases in labor supply in both the United States and Spain after their tax reforms.

The welfare gains from reducing the effective marginal tax rate on labor income in the high tax rate countries are large. The measure of welfare used is the standard one, namely, by what percentage consumption today and in all future periods must be increased in order that the households would be indifferent to the policy change in question. This measure is called the lifetime consumption equivalent measure. If France were to reduce its effective tax rate on labor income from 60 percent to the U.S. 40 percent rate, the welfare of the French people would increase by 19 percent in terms of lifetime consumption equivalents. This is a large number for a welfare gain. This measure of the welfare gain takes into consideration the reduction in leisure associated with the change in the tax system and the cost of accumulating capital associated with the higher balanced growth path. The reduction in leisure is from 81.2 hours a week to 75.8 hours, which is a 6.6 percent decline in leisure. I am surprised to find that this large tax rate decrease did not lower tax revenues. ${ }^{3}$

The welfare gains if the United States reduced its marginal tax rate on labor income are smaller. If the tax rate is reduced from 40 percent to 30 percent, the gains in terms of lifetime consumption equivalents are 7 percent.

\section{Implications for Policy}

Tax system modifications have implications for public retirement programs, such as U.S. Social Security. If labor supply is fixed, a pay-as-you-go social security system cannot be converted to a fully funded system in a way that makes every generation better off. If, however, the labor supply is not fixed, the transition can be made in a way that makes every generation better off. The only issue is how long the transition will take. Using the utility of leisure parameter, $\alpha$, obtained in the first part of this article, I now explore this issue of how long such a transition will take.

The model economy is modified is two respects. First, I follow Auerbach and Kotlikoff(1987) and use the overlapping generations structure rather than the infinitely lived family structure employed earlier. ${ }^{4}$ In the modified structure, the key relation used to forecast labor supply continues to hold. Second, the technology assumed has perfect substitution between capital and labor. The productivity of labor grows at the rate of 2 percent a year, which implies that the real wage will grow at 2 percent a year as it has on average throughout the twentieth century. The productivity of capital is constant and is such that the after-tax return is 4 percent.

Alternatively, I could have assumed that capital income tax rates, which are not formally modeled, are adjusted to maintain a 4 percent return on capital if the capital/output ratio changes as a result of the reform. This 4 percent return is the after-tax real return that has prevailed in the United States in the 1880-2002 period (McGrattan and Prescott 2003). Having some dynastic families would also work in the direction of keeping the interest rate constant.

I assume that an equal number of people begin their working career every year at age 22, they work for 41 years, and then they live an additional 19 years. This implies that they retire at 63 , which is the average U.S. retirement age. They receive social security benefits equal to 0.319 of the wage that prevailed when they were 66 beginning when they are 67 and continuing for 14 additional years. In fact, for the U.S. system, the wage base is the one that prevailed when an individual was 60 years old, so the replacement rate is approximately 36 percent. The effective tax rate on labor income is 40 percent, as it is in the United States, with 10 percent of this being a social security retirement tax. I use 10 percent rather than the U.S. 12.4 percent rate because some social security taxes are used to provide disability and survivors' benefits in the United States.

The assumption of no population growth is not realistic and introduces two errors. These errors, however, are of opposite sign and offsetting, so my example is still valid for building quantitative economic intuition. One error is that the relative number of people with social security claims is smaller if population growth is positive. This reduces the initial implicit liabilities relative to GDP of the pay-as-you-go system. The other

\footnotetext{
${ }^{3}$ Mendoza and Tesar (2002) also find that revenue is maximized with a tax rate slightly above 50 percent.

${ }^{4}$ See the July 1999 issue of the Review of Economic Dynamics, which is devoted entirely to studies of the U.S. Social Security system. These studies are much richer in detail than this one. But they do not use the utility function used in this study, and as a result, my results are different. Conesa and Garriga (2003) address the status quo problem in Social Security reform.
} 


\section{QR}

Table 4

Effects of a Shift to a Fully Funded

Social Security System

Steady States in a Model With Each System

\begin{tabular}{|c|c|c|c|c|c|c|c|}
\hline System & Output & $\frac{\text { Capital }}{\text { Output }}$ & $\begin{array}{l}\text { Labor } \\
\text { Supply }\end{array}$ & $\begin{array}{c}\text { Consumption } \\
\text { Per Person }\end{array}$ & $\begin{array}{l}\text { Soc. Sec. } \\
\text { Liabilities } \\
\text { Net Output }\end{array}$ & Welfare* & $\begin{array}{c}\text { Effective } \\
\text { Labor Tax } \\
\text { Rate }\end{array}$ \\
\hline Pay-As-You-Go & 100 & 2.77 & 100 & 100 & 4.62 & 100 & $40.0 \%$ \\
\hline Fully Funded & 123 & 4.91 & 111 & 117 & 0 & 109 & 27.05 \\
\hline
\end{tabular}

*Welfare here is measured in lifetime consumption equivalents.

error is that with a growing population the pay-as-yougo system will have higher levels of benefit payments associated with a given social security retirement tax. This increases the implicit liabilities of the current system. The pay-as-you-go system that I consider has the property that social security benefits paid are equal to social security taxes collected.

The model economy's time period is a year. The steady state of a pay-as-you-go system and a fully funded system are reported in Table 4. With the fully funded system, steady-state labor supply is 11 percent higher, consumption 17 percent higher, and welfare in lifetime consumption equivalents 9 percent higher. The problem with just switching from the current pay-asyou-go system to a fully funded system is that the initial old would suffer. The following reform makes all better off. There are still better reforms than this one, in particular, plans that have tax rates that depend upon age at the time of reform.

\section{Proposed Reform}

People are given the option to continue with the current system or to shift to a new system. With the new system, 8.7 percent of wage income is put into an individual account with the government that earns a 4 percent real return. Upon retirement, savings in this account are annuitized. Effectively, people have the option to have their tax rate on labor reduced from 40 percent to 31.3 percent and to save 8.7 percent of their labor income in a government retirement account or to continue with the current social security system. With the reform, non- social security transfers are left unchanged.

Steady-state social security liabilities of the payas-you-go system are large: 4.62 times gross national income (GNI). With the reform, those aged 37 and younger choose the new system. The welfare gain to the 22 -year-old at the time of the change exceeds 4 percent in lifetime consumption equivalents. Associated with the change, the annual capital/output ratio increases from 2.7 to 3.3, as seen in Table 5. This increase takes 45 years.

Table 5 also shows that pension liabilities of the payas-you-go system are large: 2.30 times GNI. With the new system, the decline steadily becomes zero 35 years after the reform.

\section{Some Equity Considerations}

In the model, all individuals earn the same wage when, in fact, some people earn higher wages than others. Given that earning a 4 percent after-tax real return is an attractive investment, equity considerations suggest an upper bound on contributions. Similarly, lower-income households should have the right to contribute more than 8.7 percent of their labor income.

Still another consideration is how to deal with married couples. An equitable solution is that each party has an account and household contributions are split equally between the two accounts with the contribution limit discussed above applying to an individual account and not to a household account. Some will be so unfortunate that the amount in their account will be insufficient to provide for a minimal acceptable retirement. This sug- 


\section{Table 5}

Effects of a Shift to an Optimal Government Individual Retirement Account

For 60 Years After Reform, Assuming Workers

Aged 15-37 Years Choose the New Account

\begin{tabular}{ccc}
\hline & $\begin{array}{c}\text { Soc. Sec. } \\
\text { Liabilities }\end{array}$ & \\
Year & $\frac{\text { Capital }}{\text { Output }}$ & \\
\hline 1 & 2.30 & 2.71 \\
15 & 1.57 & 2.80 \\
30 & .63 & 3.08 \\
45 & 0 & 3.31 \\
60 & 0 & 3.32
\end{tabular}

gests adding means-tested supplementary benefits.

Why force people to save, as this scheme does? The answer is that it gets around the time inconsistency problem. Some individuals will not save if they know that others will provide for their consumption whether the others are taxpayers, family members, or charities.

\section{Concluding Remarks}

In the process of determining the effect of differences in effective marginal labor tax rates on labor supply across countries and time in the advanced industrial countries, I have estimated the elasticity of labor supply and have found it to be large, nearly 3 when the fraction of time allocated to the market is in the neighborhood of the current U.S. level. This estimate of the elasticity is essentially the same one needed to account for business cycle fluctuations. That this elasticity is large is good news. If labor supply were inelastic, the advanced industrial countries would face a cruel choice of either increasing taxes on the young, thereby lowering young people's welfare, or not honoring the promises made to the old, making the old worse off.

The large labor supply elasticity means that as populations age, promises of payments to the current and future old cannot be financed by increasing tax rates. These promises can be honored by reducing the effective marginal tax rate on labor and moving toward retirement systems with the property that benefits on margin increase proportionally to contributions. Requiring people to save for their retirement years is not a tax and does not reduce labor supply. My example establishes that reforms are possible that benefit the current young workers and future workers while honoring promises made to the old.

One factor that I ignored in my social security reform example is that a larger capital/labor ratio increases wages with any reasonable aggregate production function. If this factor is taken into consideration, the welfare gains are larger. It is beyond the scope of this article to more than scratch the surface of how best to reform the social security retirement system and what the resulting welfare gains would be. But it is clear, given the high responsiveness of labor supply to marginal labor tax rates, that the potential gains are great. 


\section{Appendix}

\section{Data Sources}

1. Source of national accounts (SNA) statistics: United Nations $(1982,2000)$.

2. Source of civilian employment, noncivilian employment, annual hours per employee, population aged 15-64: OECD Labour Database, available at http://www.oecd.org/home/. Follow links to Statistics, Labour, and Labour Force Statistics-Data.

"Hours of work: manufacturing" data are used for Japan in 1970-71 because annual hours per employee for Japan in 1970-71 are not in the OECD Labour Database. These data are obtained from United Nations (1981). They are based on establishment study.

3. Source of purchasing power parity GDP numbers in Table 1: OECD Annual National Accounts Statistics, Table B.3 (OECD 2001), available at http://www.sourceoced.org. Follow links to Statistics, OECD Statistics, and National Accounts.

4. Source of income taxes and contributions for Social Security, United States: BEA Table 3.2., available at http://www.bea.gov/bea/dn/nipaweb/SelectTable. asp?Selected $=$ Y\#S3.

5. Source of national accounts statistics for Spain: Instituto Nacional de Estadística (Spain Statistical Office), available at http://www.ine.es/inebase/menu3i.htm\#15.

Download the annual national accounts for the period 1993-2001. 
Why Americans Work So Much

Edward C. Prescott

\section{References}

Auerbach, Alan J., and Kotlikoff, Laurence J. 1987. Dynamic fiscal policy. Cambridge: Cambridge University Press.

Baxter, Marianne, and King, Robert G. 1993. Fiscal policy in general equilibrium. American Economic Review 83 (June): 315-34.

Bergoeing, Raphael; Kehoe, Patrick J.; Kehoe, Timothy J.; and Soto, Raimundo. 2002. A decade lost and found: Mexico and Chile in the 1980s. Review of Economic Dynamics 5 (January): 166-205.

Boldrin, Michele; Christiano, Lawrence J.; and Fisher, Jonas D. M. 2001. Habit persistence, asset returns, and the business cycle. American Economic Review 91 (March): 149-66.

Chari, V. V.; Kehoe, Patrick J.; and McGrattan, Ellen R. 2003. Accounting for the Great Depression. Federal Reserve Bank of Minneapolis Quarterly Review 27 (Spring): 2-8.

Christiano, Lawrence J., and Eichenbaum, Martin. 1992. Current real-businesscycle theories and aggregate labor-market fluctuations. American Economic Review 82 (June): 430-50.

Cole, Harold L., and Ohanian, Lee E. 1999. The Great Depression in the United States from a neoclassical perspective. Federal Reserve Bank of Minneapolis Quarterly Review 23 (Winter): 2-24

2002. The Great U.K. Depression: A puzzle and possible resolution. Review of Economic Dynamics 5 (January): 19-44.

Conesa, Juan Carlos, and Garriga, Carlos. 2003. Status quo problem in Social Security reforms. Macroeconomic Dynamics 7 (November): 691-710.

Cooley, Thomas F., ed. 1995. Frontiers of business cycle research. Princeton: Princeton University Press.

Davis, Steven J., and Henrekson, Magnus. 2003. Tax effects on work activity, industry mix and shadow economy size: Evidence from rich-country comparisons. Manuscript. University of Chicago Graduate School of Business.

Feenberg, Daniel R., and Coutts, Elisabeth. 1993. An introduction to the TAXSIM model. Journal of Policy Analysis and Management 12 (Winter): 189-94.

Feldstein, Martin. 1995. The effect of marginal tax rates on taxable income: A panel study of the 1986 Tax Reform Act. Journal of Political Economy 103 (June): 551-72.

Feldstein, Martin, and Feenberg, Daniel R. 1993. Higher tax rates with little revenue gain: An empirical analysis of the Clinton tax plan. Tax Notes 58 (March): 1653-57.

Fisher, Jonas D. M., and Hornstein, Andreas. 2002. The role of real wages, productivity, and fiscal policy in Germany's Great Depression 1928-1937. Review of Economic Dynamics 5 (January): 100-27.

Hansen, Gary D. 1985. Indivisible labor and the business cycle. Journal of Monetary Economics 16 (November): 309-27.

Kehoe, Timothy J., and Prescott, Edward C. 2002. Great depressions of the 20th century. Review of Economic Dynamics 5 (January): 1-18.

Kydland, Finn E., and Prescott, Edward C. 1982. Time to build and aggregate fluctuations. Econometrica 50 (November): 1345-70.

Kydland, Finn E., and Zarazaga, Carlos E. J. M. 2002. Argentina's lost decade. Review of Economic Dynamics 5 (January): 152-65.
Lucas, Robert E., Jr. 1972. Expectations and the neutrality of money. Journal of Economic Theory 4 (April): 103-24.

Lucas, Robert E., Jr., and Rapping, Leonard A. 1969. Real wages, employment, and inflation. Journal of Political Economy 77 (September/October): 721-54.

Maddison, Angus. 1995. Monitoring the world economy: 1820-1992. Development Centre Studies. Paris: Organisation for Economic Co-operation and Development.

McGrattan, Ellen R., and Prescott, Edward C. 2000. Is the stock market overvalued? Federal Reserve Bank of Minneapolis Quarterly Review 24 (Fall): 20-40.

.2002. Taxes, regulations, and the value of U.S. corporations: A general equilibrium analysis. Research Department Staff Report 309. Federal Reserve Bank of Minneapolis, August.

2003. Average debt and equity returns: Puzzling? American Economic Review 93 (May): 392-97.

McGrattan, Ellen R., and Rogerson, Richard. 1998. Changes in the hours worked since 1950. Federal Reserve Bank of Minneapolis Quarterly Review 22 (Winter): 2-19.

Mendoza, Enrique G.; Razin, Assaf; and Tesar, Linda L. 1994. Effective tax rates in macroeconomics: Cross-country estimates of tax rates on factor incomes and consumption. Journal of Monetary Economics 34 (December): 297-323.

Mendoza, Enrique G., and Tesar, Linda L. 2002. Tax competition v. tax coordination under perfect capital mobility: The supply-side economics of international tax competition. CEPR 4th Conference of the Analysis of International Capital Markets Research Training Network, November.

Nickell, Stephen. 2003. Employment and taxes. Manuscript. Venice International Institute.

Organisation for Economic Co-operation and Development (OECD). 2001. National accounts of OECD countries, volume I: Main aggregates, CD-ROM on beyond 20/20. Paris: Organisation for Economic Co-operation and Development, January.

Olovsson, Conny. 2003. Why do Europeons work so little? Manuscript. International Institute for Economic Studies, Stockholm University.

Rogerson, Richard D. 2003. The employment effects of taxes. Working paper presented at Dynamic Economics Conference in Honor of Edward C. Prescott, 29 April, Federal Reserve Bank of Chicago.

United Nations. 1981. 1979/80 statistical yearbook, 31 st issue. Department of International Economic and Social Affairs. New York: United Nations.

1982. Yearbook of national accounts statistics 1980, Part 1 and Part 2. New York: United Nations.

2000. National accounts statistics: Main aggregates and detailed tables. New York: United Nations.

U.S. Department of the Treasury, Internal Revenue Service. 1974. Statistics of income, individual income tax returns 1972. Washington, D.C.: U.S. Government Printing Office.

1996. Statistics of income, individual income tax returns 1994 Washington, D.C.: U.S. Government Printing Office. 